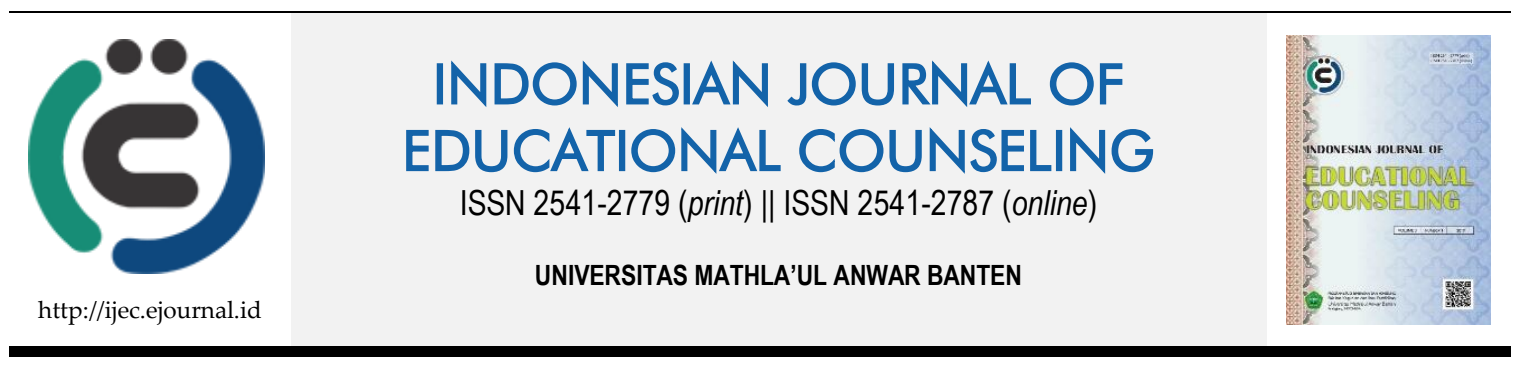

Research Based Article

\title{
Keefektifan Konseling Realita untuk Mengatasi Kecemasan Mengemukakan Pendapat pada Siswa SMP
}

\author{
Dwi Istiqomah"1, Bakhrudin All Habsy² \\ ${ }^{1}$ SMP Negeri 2 Kutorejo, Mojokerto, ${ }^{2}$ Universitas Darul Ulum, Jombang
}

\begin{tabular}{|c|c|}
\hline Article History & ABSTRACT \\
\hline $\begin{array}{l}\text { Received: } 18.08 .2018 \\
\text { Received in revised form: } \\
22.10 .2018 \\
\text { Accepted: } 03.01 .2019 \\
\text { Available online: } 25.01 .2019\end{array}$ & $\begin{array}{l}\text { This study aims to test the effectiveness of reality counseling to overcome the } \\
\text { level of anxiety express opinions of students in junior high. This research uses } \\
\text { pre experimental pre-test type posttest one group design. The data analysis } \\
\text { used is paired test of T-test, to see the change of anxiety level in experimental } \\
\text { group between pretest and posttest by looking at } t \text { table price at degrees of } \\
\text { freedom (dk), that is the magnitude is } \mathrm{N}-1 \text {, and at a significant level } \alpha=0,05 \\
(95 \%) \text { then we get } \mathrm{t} \text {-table }=1,833 \text {, assuming if } \mathrm{t} \text { count }>\mathrm{t} \text {-table then Ha } \\
\text { "received". From the test results using T-Test proves that effective reality } \\
\text { counseling in overcoming anxiety expressed the opinion of junior high school } \\
\text { students. Because } \mathrm{t} \text { arithmetic } 16,628>\mathrm{t} \text { table } 1,833 \text { on the significant level } \alpha= \\
0,05 \text {, then Ha "accepted". Based on the findings of the research, for the next } \\
\text { researcher, with the findings of reality counseling implementation to overcome } \\
\text { the level of anxiety to express the opinion of the students, should be an } \\
\text { inspiration in doing further research by applying counseling with other } \\
\text { therapies, especially in an effort to overcome the anxiety level express opinion } \\
\text { to the students. }\end{array}$ \\
\hline & Keywords: Anxiety Pose Opinion, Reality Counseling. \\
\hline
\end{tabular}

DOI: $10.30653 / 001.201931 .48$

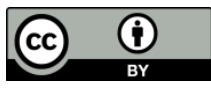

This is an open access article distributed under the terms of the Creative Commons Attribution 4.0 International License, which permits unrestricted use, distribution, and reproduction in any medium, provided the original work is properly cited. (c) 2019 Dwi Istiqomah, Bakhrudin All Habsy.

\section{PENDAHULUAN}

Siswa SMP dalam tahap perkembangannya digolongkan sebagai masa remaja awal yakni dari 13-15 tahun, sedangkan remaja madya: 15-18 tahun, dan remaja akhir: 19-22 tahun, masa remaja awal yang secara psikologis belum memperoleh kestabilan emosi sehingga mudah terpengaruh oleh sesuatu yang berasal dari luar dirinya. Pernyataan tersebut didukung pendapat Habsy (2017) yang menyatakan bahwa pada saat individu memasuki tahapan pendidikan di sekolah menengah, masa remaja adalah masa peralihan dari masa kanak-kanak menuju masa dewasa.

${ }^{1}$ Corresponding author’s address: SMP Negeri 2 Kutorejo; JL. Singowangi Kecamatan Kutorejo, Mojokerto; Email: dwiistiqomah113@gmail.com 
Pada masa ini banyak remaja yang mengalami gangguan yang bersifat psikis, psikologis serta emosional. Hal ini disebabkan belum stabilnya kemampuan diri individu pada usia remaja dalam menjalani kehidupan. Salah satu contoh gangguan yang sering dialami siswa adalah munculnya rasa cemas (Hurlock, 2009, p. 69). Kecemasan merupakan suatu keadaan psikologis dimana individu terus menerus berada dalam perasaan khawatir yang kurang jelas dan menyakitkan yang ditimbulkan oleh inner conflict atau kecemasan-kecemasan dalam alat-alat intern (Morgan, 2004, p. 8). Sedangkan Joesoef (dalam Suryabrata, 2007, p. 5), mengatakan bahwa kecemasan merupakan suatu kumpulan gejala yang berdasar rasa takut dimana sumber rasa takutnya adalah terhadap sesuatu yang tidak nyata dan tidak jelas, atau disebut free floating anxiety. Jika tidak diatasi, kecemasan dapat mengarah pada depresi. Depresi pada umumnya menunjukkan gejala psikis, gejala fisik dan sosial yang khas, seperti murung, sedih berkepanjangan, sensitif, mudah marah dan tersinggung, hilang semangat, hilangnya rasa percaya diri, hilangnya konsentrasi, dan menurunnya daya tahan (Hidayat \& Sahrudin, 2016, p. 174).

Karakteristik siswa mengalami kecemasan antara dibagi dua adalah 1) gejala fisik meliputi: ujung-ujung jari terasa dingin, pencernaan kurang teratur, keringat bercucuran, pukulan jantung cepat, 2).gejala mental atau psikis yang meliputi: perhatian kurang terpusat, sangat takut, tidak berdaya atau rendah diri. Tanda-tanda kecemasan sebagai berkut: debaran-debaran, gemetar, cemas, berkeringat, gugup, dan atau tanda-tanda fisik lain (Prasetyono, 2009, p. 32).

Menurut Wahyuni (2015), ada empat faktor utama yang mempengaruhi kecemasan, diantranya: 1) lingkungan atau tempat tinggal mempengaruhi cara berpikir tentang diri sendiri ataupun orang lain, hal ini bisa saja disebabkan pengalaman dengan keluarga, dan lain-lain, 2) emosi yang ditekan, kecemasan bisa terjadi jika tidak mampu menemukan jalan keluar untuk perasaan dalam hubungan personal, 3) sebab-sebab fisik, pikiran dan tubuh senantiasa berinteraksi dan dapat menyebabkan timbulnya kecemasan dan 4) keturunan, sekalipun gangguan emosi ada yang ditemukan dalam keluarga-keluarga tertentu, ini bukan merupakan penyebab penting dari kecemasan dapat ditimbulkan oleh konflik-konflik emosional, frustasi-frustasi dan kecemasan -kecemasan batin yang dalam situasi tertentu dianggap sebagai ancaman yang banyak mengandung kemungkinankemungkinan buruk.

Kecemasan mengemukakan pendapat dalam penelitian ini adalah suatu keadaan psikologis dimana individu terus menerus dalam keadaan khawatir yang kurang jelas dan menyakitkan ketika mengemukakan pendapat aspek dari diantaranya 1) aspek fisiologis yang meliputi: detak jantung cepat, nafas sesak, keringat bercucuran, sebentarsebentar ingin buang air kecil, muka pucat, badan gemetaran, tidak berani menatap lawan bicara/menundukan kepala, kepala pusing, badan terasa lemas. 2) Aspek psikologis meliputi: tidak percaya diri, tidak konsentrasi, tidak mampu mengembangkan kualitas diri, tidak memiliki pertimbangan dan pengarahan yang rasional, tegang, cemas, frustasi, lari dari kenyataan.

Fenomena seperti ini tentunya menjadi permasalahan tersendiri bagi keberhasilan pelaksanaan pengajaran di kelas. Seorang siswa yang mengalami kecemasan saat mengemukakan pendapat dimungkinkan dapat menghambat kinerjanya di kelas tersebut, Hal ini masih banyak dijumpai pada siswa-siswa disekolah SMP di Kab. Mojokerto, salah satu bantuan yang dapat diberikan kepada siswa yaitu dengan memanfaatkan layanan bimbingan dan konseling. Dalam layanan bimbingan dan 
konseling terdapat salah satu layanan untuk menangani hal tersebut dengan memberikan layanan konseling. Menurut Habsy (2017) layanan konseling merupakan bagian integral dari sistem pendidikan Nasional yang mengacu pada pencapaian tujuan pendidikan Nasional, dan sejalan dengan tujuan bimbingan dan konseling sebagai ilmu.

Pendekatan Konseling Realita dipilih untuk menangani kecemasan dalam mengemukakan pendapat dalam penelitian ini. Menurut Glasser (dalam Corey, 2015) menyatakan bahwa konseling realita mambantu para konseli dalam memenuhi kebutuhan-kebutuhan dasar psikologisnya yang mencakup kebutuhan untuk mencintai dan dicintai serta kebutuhan untuk merasakan bahwa kita berguna baik bagi diri kita sendiri maupun bagi orang lain.

Dalam konseling realita, konselor berfungsi sebagai guru dan model serta mengkonfrontasikan konseli dengan cara-cara yang bisa membantu konseli menghadapi kenyataan dan memenuhi kebutuhan-kebutuhan dasar tanpa merugikan diri sendiri maupun orang lain, serta berani memikul tanggung jawab atas semua. Konseling realita juga memandang konseling sebagai suatu proses yang rasional. Dalam poses tersebut, konselor dituntut mampu menciptakan suasana yang hangat, penuh pengertian, dan yang paling penting adalah menumbuhkan pengertian konseli bahwa dia harus mampu bertangung jawab bagi dirinya sendiri. Konselor diharapkan mampu memerankan sebagai guru yang menciptakan situasi kondusif mengajar, memberi contoh serta mengajak konseli untuk menghadapi realita. Oleh karena setiap orang, termasuk siswa selalu diharapkan pada kenyataan, maka pendekatan ini tepat untuk diterapkan oleh konselor dalam mengatasi masalah-masalah psikologis dan perilaku-perilaku/perbuatan yang tidak realita atau yang tidak sesuai. Secara sederhana perilaku/perbuatan tidak sesuai digambarkan sebagai individu yang kurang terlibat dengan orang lain, tidak pernah belajar untuk berbuat secara bertangungjawab, cenderung mengabaikan prinsip 3 R, yaitu Right, Responsibility dan Reality (Hansen dalam Habsy, 2018).

Konseling realita tampaknya merupakan cara yang cukup efektif guna mengatasi kecemasan berpendapat pada diri siswa, namun keefektifan dari konseling realita ini masih perlu untuk diuji. Oleh sebab itu penelitian ini dilakukan untuk menguji keefektifan konseling realita untuk mengatasi kecemasan berpendapat pada diri siswa. Dari uraian latar belakang di atas penulis merasa tertarik untuk mengadakan penelitian lebih lanjut mengenai hal tersebut.

\section{METODE}

Desain atau rancangan penelitian merupakan suatu proses yang diperlukan dalam perencanaan dan pelaksanaan sebuah penelitian (Habsy, 2017). Dalam penelitian ini, peneliti menggunakan pendekatan kuantitatif dengan rancangan penelitian yang dipakai oleh peneliti adalah rancangan penelitian eksperimen yang berbentuk one group pretestposttest design.

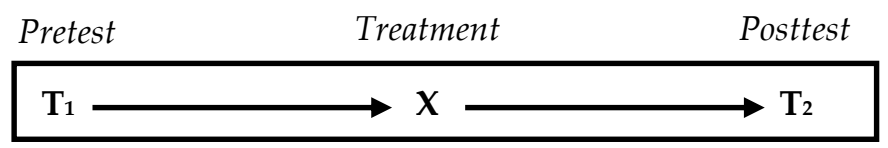

Gambar 1. Rancangan Penelitian 


\section{Keterangan:}

$\mathrm{T}_{1}$ : pretest, untuk mengukur mean kecemasan mengemukakan pendapat sebelum siswa diberi konseling realita

$\mathrm{T}_{2}$ : posttest, untuk mengukur mean kecemasan mengemukakan pendapat sesudah siswa diberi konseling realita

$X \quad$ : treatment yaitu konseling realita

Berdasarkan Gambar 1, dapat diuraikan kegiatan pertama yang dilakukan oleh peneliti adalah melakukan pretes dengan menyebarkan angket kecemasan mengemukakan pendapat, kemudian subjek yang mengalami kecemasan mengemukakan pendapat berdasarkan pengukuran akan diberikan treatment (perlakuan) berupa konseling realita lalu melakukan postes dengan angket untuk melakukan pengukuran akhir. Secara visual kerangka kerja konseling realita untuk mengatasi kecemasan mengemukakan pendapat siswa SMP, diilustrasikan dalam Gambar 2.

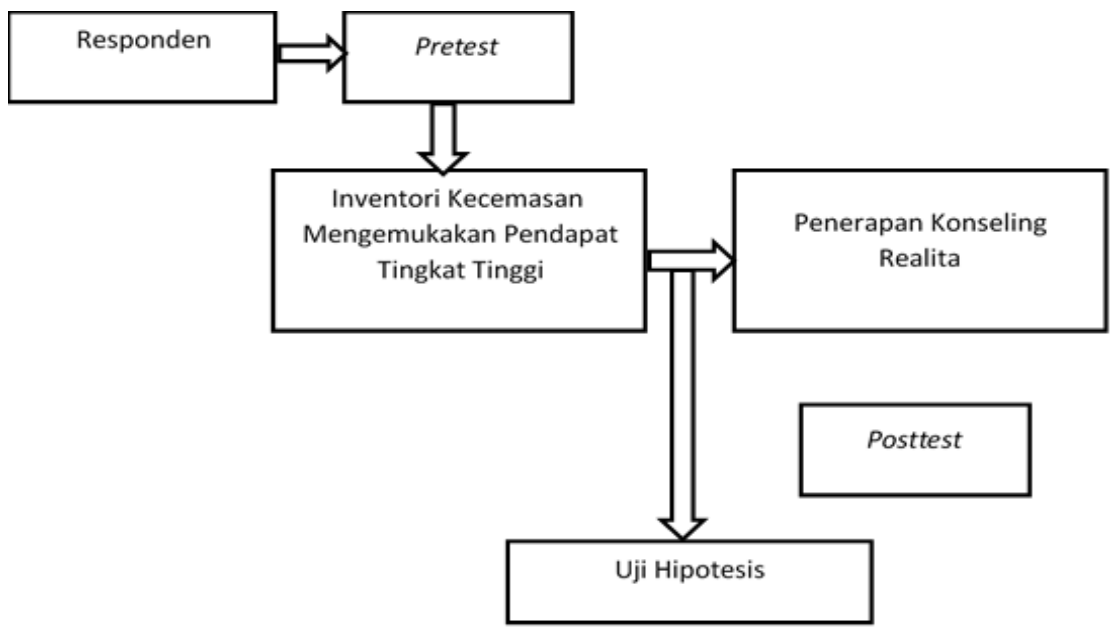

Gambar 2. Kerangka Penelitian

(Diadaptasi dari Habsy, 2018)

\section{Populasi Penelitian}

Populasi dalam penelitian ini adalah siswa kelas VIII F-G SMP, yang berjumlah 64 . Untuk lebih jelasnya tentang populasi penelitian ini, bisa dilihat pada tabel 1 berikut ini.

Tabel. 1. Populasi Penelitian

\begin{tabular}{lllll}
\hline No & Kelas & Laki-laki & Perempuan & Jumlah \\
\hline 1 & VIII-F & 17 & 15 & 32 \\
\hline 2 & VIII-G & 19 & 13 & 32 \\
\hline & & 36 & 28 & 64 \\
\hline
\end{tabular}

Dari populasi pada Tabel 1, dipilih beberapa siswa untuk menjadi subjek penelitian sebagai kelompok eksperimen, dimana pengambilan sampel berdasarkan, data siswa yang mengalami kecemasan mengemukakan pendapat tingkat tinggi pada pengukuran 
inventori. Pemilihan subjek penelitian ditentukan berdasarkan pemenuhan kriteriakriteria: 1) Tercatat sebagai siswa SMPN 2 Kutorejo, pada tahun ajaran 2017/2018; 2) Teridentifikasi sebagai siswa dengan kecemasan mengemukakan pendapat berdasarkan alat ukur inventori yang digunakan dalam penelitian ini; 3) Bersedia mengikuti seluruh kegiatan intervensi yang dilakukan peneliti dan mengisi lembar persetujuan yang disediakan oleh peneliti.

\section{Instrumen Penelitian}

Instumen penelitian dalam penelitian ini menggunakan angket kecemasan mengemukakan pendapat yang terdiri dari 2 indikator yaitu 1).Aspek Fisiologis yang meliputi: detak jantung cepat, nafas sesak, keringat bercucuran, sebentar-sebentar ingin buang air kecil, muka pucat, badan gemetaran, tidak berani menatap lawan bicara, kepala pusing dan badan terasa lemas. 2) Aspek psikologis meliputi: tidak percaya diri, tidak konsentrasi, tidak mampu mengembangkan kwalitas diri, dan pengarahan yang rasional, tegang, cemas, frustasi, lari dari kenyataan, yang sudah teruji validitas dan reliabilitasnya.

\section{Analisis Data}

Setelah data-data yang dibutuhkan terkumpul maka tahap selanjutnya dalam penelitian ini adalah analisis data. Menurut Ghozali, (2012, p. 160), menganalisa data dalam penelitian adalah untuk mencari signifikansi perbedaan antara tes sebelum perlakuan dan sesudah perlakuan yang menunjukan kuat lemahnya Efektivitas variabel $\mathrm{X}$ dalam mempengaruhi variabel $\mathrm{Y}$, menggunakan rumus Paired Samples T-test sebagai berikut:

$$
\boldsymbol{t}=\frac{\bar{M} d}{\sqrt{\frac{\sum x^{2} d}{N(N-1)}}}
$$

Keterangan:

$$
\begin{aligned}
\bar{M} d & =\text { mean } \text { dari deviasi (d) antara posttest dan pretest } \\
x^{2} d & =\text { perbedaan deviasi dengan mean deviasi } \\
N & =\text { banyaknya subyek } \\
d f & =\text { atau db adalah } \mathrm{N}-1
\end{aligned}
$$

Selanjutnya untuk proses analisis data yang lebih akurat dan efisien dalam perhitungannya, maka perhitungan analisis data akan dikerjakan dengan menggunakan program SPSS 20 for Windows.

\section{HASIL DAN PEMBAHASAN}

Proses intervensi terhadap subjek yang telah terjaring dilaksanakan selama 1 bulan, dimulai 16 April dan berakhir pada 16 Mei 2018. Intervensi dilakukan oleh Peneliti yang berperan sebagai Konselor. Pretest diberikan di awal intervensi untuk mengetahui kriteria kecemasan berpendapat siswa sebelum pemberian intervensi. setelah itu diberikan Posttest. Berikut tabel siswa yang tergolong kecemasan mengemukakan pendapat tinggi berdasarkan pengukuran:

Tabel 2. Hasil Pretest Siswa yang tergolong Kecemaan Mengemukakan Pendapat Tingkat Tinggi 


\begin{tabular}{llll}
\hline No. & Responden & Skor & Kategori \\
\hline 1. & AJS & 115 & Tinggi \\
\hline 2. & GAA & 114 & Tinggi \\
\hline 3. & KOR & 113 & Tinggi \\
\hline 4. & MMF & 116 & Tinggi \\
\hline 5. & MAP & 113 & Tinggi \\
\hline 6. & RDA & 114 & Tinggi \\
\hline 7. & DA & 106 & Tinggi \\
\hline 8. & DF & 110 & Tinggi \\
\hline 9. & FPN & 110 & Tinggi \\
\hline 10. & SDC & 112 & Tinggi \\
\hline
\end{tabular}

Hasil perolehan skor pretest kecemasan mengemukakan pendapat siswa tinggi tersebut secara jelas dapat digambarkan dalam grafik berikut.

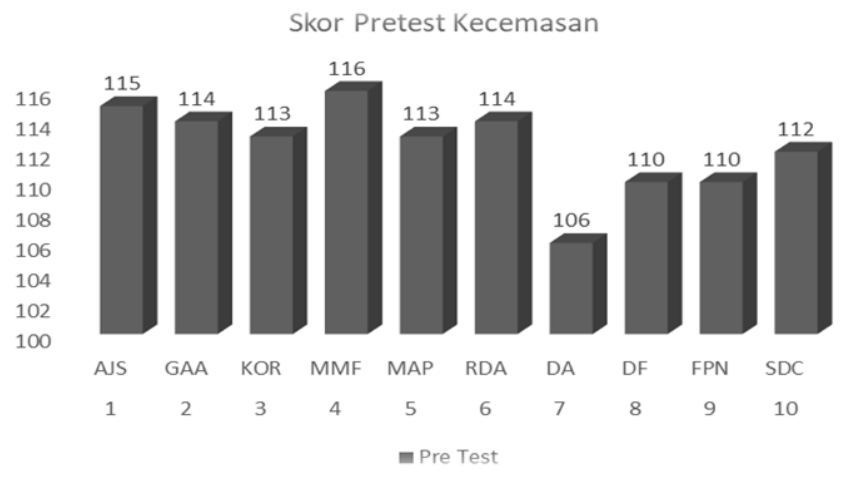

Gambar 3. Skor Pretest

Berdasarkan hasil pre-test dapat diketahui bahwa dari 64 responden terdapat sebanyak 10 responden yang berada dalam skor diatas rata-rata, yang artinya ada 10 responden yang dalam kecemasan mengemukakan pendapat tingkat tinggi. Berikut data keefektifan konseling realita pretest dan posttest pada 10 responden kecemasan mengemukakan pendapat tingkat tinggi sebelum dan sesudah diberi konseling realita:

Tabel 3. Hasil Pretest-Posttest

\begin{tabular}{llllllll}
\hline No. & Konseli & Pretest & Kriteria & Posttest & Kreteria & Arah Perbedaan & Point \\
\hline 1. & AJS & 115 & Tinggi & 96 & Sedang & $(\mathrm{A} 1)>(\mathrm{A} 2)$ & 7 \\
\hline 2. & GAA & 114 & Tinggi & 96 & Sedang & $(\mathrm{A} 1)>(\mathrm{A} 2)$ & 15 \\
\hline 3. & KOR & 113 & Tinggi & 97 & Sedang & $(\mathrm{A} 1)>(\mathrm{A} 2)$ & 14 \\
\hline 4. & MMF & 116 & Tinggi & 93 & Sedang & $(\mathrm{A} 1)>(\mathrm{A} 2)$ & 8 \\
\hline 5. & MAP & 113 & Tinggi & 97 & Sedang & $(\mathrm{A} 1)>(\mathrm{A} 2)$ & 9 \\
\hline 6. & RDA & 114 & Tinggi & 94 & Sedang & $(\mathrm{A} 1)>(\mathrm{A} 2)$ & 13 \\
\hline 7. & DA & 106 & Tinggi & 91 & Rendah & $(\mathrm{A} 1)>(\mathrm{A} 2)$ & 8 \\
\hline 8. & DF & 110 & Tinggi & 90 & Rendah & $(\mathrm{A} 1)>(\mathrm{A} 2)$ & 14 \\
\hline 9. & FPN & 110 & Tinggi & 95 & Sedang & $(\mathrm{A} 1)>(\mathrm{A} 2)$ & 13 \\
\hline 10. & SDC & 112 & Tinggi & 95 & Sedang & $(\mathrm{A} 1)>(\mathrm{A} 2)$ & 15 \\
\hline
\end{tabular}


Adapun poin frekuensi kecemasan mengemukakan pendapat siswa sebelum diberi konseling realita (A1) dan kecemasan mengemukakan pendapat siswa sesudah diberi konseling realita (A2) tersebut secara jelas tergambar dalam Gambar 4.

\section{Skor Pretest-Postest}

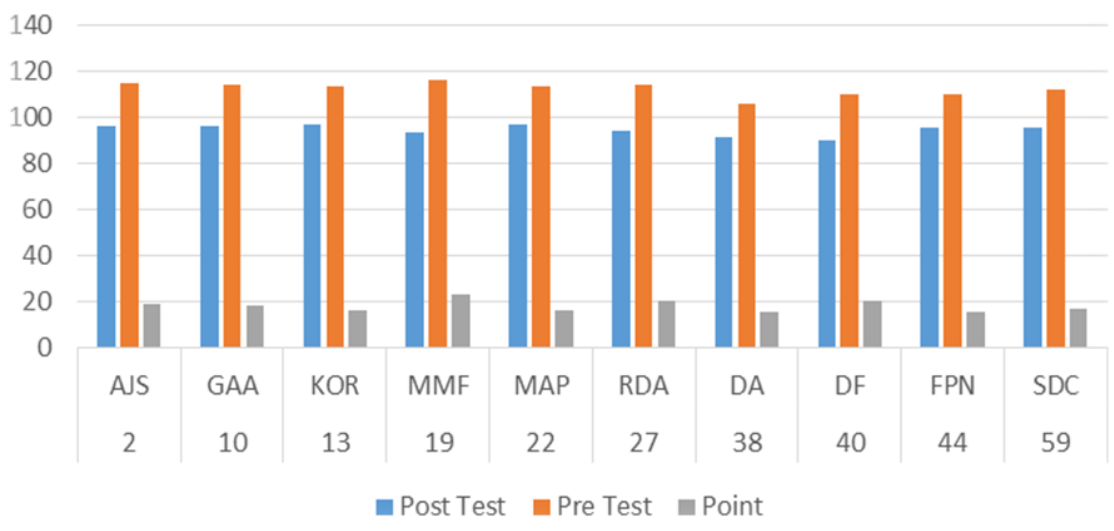

Gambar 4. Kecemasan Mengemukakan Pendapat Siswa Sebelum dan Sesudah diberi Konseling Realita

\section{Pengujian Hipotesis}

Berdasarkan rumusan masalah yang diajukan, maka terdapat hipotesis yang harus diuji dalam penelitian adalah Untuk mengidentifikasi ada tidaknya keefektifan konseling realita untuk menurunkan kecemasan mengemukakan pendapat, penulis menggunakan analisa data kuantitatif. Adapun rumus yang digunakan adalah rumus T-test. Selanjutnya penghitungan dilakukan dengan bantuan komputer program SPSS 20 for windows. T-tes adalah rumus yang digunakan khusus dalam menguji hipotesis yang berisi tentang sifat dan kemampuan (traits and ability). Adapun uji t yang digunakan adalah Paired-sample Ttest. Untuk melihat harga $\mathrm{t}$ tabel maka didasarkan pada derajat kebebasan ( $\mathrm{dk})$, yaitu besarnya adalah $\mathrm{N}-1$, yaitu 10-1 = 9 dan pada taraf signifikan $\alpha=0,05$ (95\%) maka didapatkan $t$ tabel $=1,833$, dengan asumsi jika $t$ hitung $>t$ tabel maka $\mathrm{Ha}_{a}$ "diterima"

Berdasarkan hasil analisis uji $\mathrm{t}$ dua sampel berpasangan diperoleh hasil sebagai berikut: $\mathrm{t}$ hitung lebih besar dari $\mathrm{t}$ tabel $(16,628>1,833)$. Karena nilai $\mathrm{t}$ hitung $>\mathrm{t}$ tabel, maka hipotesis yang penulis ajukan berupa hipotesis alternatif (Ha) yang berbunyi terdapat efektivitas konseling realita untuk mengurangi kecemasan mengemukakan pendapat siswa SMP "diterima". Selanjutnya diketahui bahwa nilai t bertanda positif, ini mempunyai arti bahwa variabel bebas (konseling realita) mempunyai pengaruh yang signifikan dalam mempengaruhi variabel terikat (kecemaan mengemukakan pendapat).

\section{Diskusi}

Kecemasan mengemukakan pendapat merupakan suatu keadaan psikologis, dimana individu terus menerus dalam keadaan khawatir yang kurang jelas dan menyakitkan ketika mengemukakan pendapat. Kecemasan disebabkan oleh rasa-rasa bersalah dan berdosa serta konflik-konflik emosional yang serius dan kronis berkesinambungan, frustasi-frustasi dan kecemasan batin". siswa ketika didalam kelas akan menghadapi problematika jika dia tidak dapat mengendalikan kecemasan yang 
sering dialami oleh siswa ketika didalam kelas yaitu pada saat mengemukakan pendapat. Untuk mengetahui bahwa kesan sulitnya mengemukakan pendapat merupakan hal yang sering ditakuti oleh para siswa maka para siswa lebih memilih diam ketika ada sesi pertanyaan dan tidak pernah mengemukakan idenya. Bahkan tidak jarang ada siswa yang membolos atau pura-pura sakit dan meninggalkan kelas pada saat pelajaran. Sebenarnya mereka mampu dan paham tetapi rasa cemas telah menghambat kemampuan dan pemahaman mereka

Sesuai dengan fungsi dan tujuan eksistensi layanan bimbingan dan konseling terutama konseling realita yaitu sebagai aternatif bantuan untuk menurunkan tingkat kecemasan mengemukakan pendapat siswa, maka 10 siswa yang tergolong tinggi kecemasan mengemukakan pendapatnya diberikan konseling realita dan dengan adanya perlakuan ini, diharapkan terjadi perubahan pada kecemasan mengemukakan pendapat siswa tingkat tinggi yang mereka miliki menuju perubahan yang lebih baik, diantara ciriciri kecemasan mengemukakan pendapat yang dijadikan indikator sebagai berikut: 1) Aspek fisiologis yang meliputi: detak jantung cepat, nafas sesak, keringat bercucuran, sebentar-sebentar ingin buang air kecil, muka pucat, badan gemetaran, tidak berani menatap lawan bicara/menundukan kepala, kepala pusing dan badan terasa lemas. 2) Aspek psikologis meliputi: tidak percaya diri, tidak konsentrasi, tidak mampu mengembangkan kwalitas diri, tidak memiliki pertimbangan dan pengarahan yang rasional, tegang, cemas, frustasi, lari dari kenyataan.

Hal di atas sesuai seperti diungkap Joesoef (dalam Suryabrata, 2007:5) yang mengatakan bahwa kecemasan merupakan suatu kumpulan gejala yang berdasar rasa takut dimana sumber rasa takutnya adalah terhadap sesuatu yang tidak nyata, tidak jelas yang nama lainnya yaitu free floating anxiety, nonsituasional atau general anxiety. Hal senada Morgan, (2004:8) mengungkapkan bahwa kecemasan merupakan suatu keadaan psikologis dimana individu terus menerus berada dalam perasaan khawatir yang kurang jelas dan menyakitkan yang ditimbulkan oleh inner conflict atau kecemasan-kecemasan dalam alat-alat intern.

Hasil treatment atau perlakuan berupa konseling realita terhadap 10 responden yang skor minat kecemasan mengemukakan pendapatnya tinggi, terjadi perubahan dari siswa yang memiliki kecemasan mengemukakan pendapat yang tinggi setelah mengikuti kegiatan konseling realita mengalami penurunan yaitu berada dalam kategori sedang. Hal ini dapat dilihat berdasarkan hasil posttest terhadap kecemasan mengemukakan pendapat pada siswa SMP setelah konseling realita secara empiris diketahui skor maksimal yang dicapai adalah 97 dan skor minimal adalah 90, rata-rata (mean) 95, dan standar deviasi adalah 2,38. Dari tabel 4,8. dapat diketahui bahwa sebanyak 2 responden $(20 \%)$ memiliki skor dibawah rata-rata dari skor kecemasan mengemukakan pendapat. Sedangkan 8 responden $(80 \%)$ memiliki skor sama dengan rata-rata dan sebanyak 0 responden $(0,00 \%)$ memiliki skor di atas rata-rata dari skor kecemasan mengemukakan pendapat setelahkonseling realita. Dengan demikian dapat disimpulkan bahwa kecemasan mengemukakan pendapat siswa setelah diberi konseling realita termasuk kategori "sedang" karena banyak responden yang memiliki skor bawah dan rata-rata dan rata-rata (mean).

Hal ini seperti yang diungkapkan (Gunarsa, 1991, p. 212). Yang mengatakan bahwa konseling realita merupakan terapi untuk memberikan kemungkinan dan kesempatan kepada klien, agar mereka dapat mengembangkan kekuatan-kekuatan psikis yang 
dimilikinya untuk menilai prilaku sekarang dan apabila prilakunya tidak dapat memenuhi kebutuhan-kebutuhannya, maka memperoleh prilaku baru yang lebih efektif. Hal senada juga diungkap Kartono (2013, pp. 130-131) yang mengatakan bahwa kecemasan disebabkan oleh rasa-rasa bersalah dan berdosa serta konflik-konflik emosional yang serius dan kronis berkesinambungan, frustasi-frustasi dan kecemasan batin".

Berdasarkan hasil analisis uji $\mathrm{t}$ dua sampel berpasangan dapat diperoleh hasil sebagai berikut: $t$ hitung lebih besar dari $t$ tabel $(16.628>1.833)$. Karena nilai $t$ hitung $>t$ tabel, maka hipotesis yang penulis ajukan berupa hipotesis alternatif (Ha) yang berbunyi terdapat efektivitas konseling realita untuk mengurangi kecemasan mengemukakan pendapat siswa SMP"diterima". Selanjutnya dapat diketahui bahwa nilai $t$ bertanda positif, ini mempunyai arti bahwa variabel bebas (konseling realita) mempunyai pengaruh yang signifikan dalam mempengaruhi variabel terikat (kecemaan mengemukakan pendapat). Artinya jika variabel konseling realita $(X)$ ditingkatkan maka akan berdampak untuk mengurangi kecemasan mengemukakan pendapat siswa. Hal ini sesuai dengan apa yang diungkapkan (Corey, 2015). Bahwa: konseling realita merupakan suatu sistem yang difokuskan pada tingkah laku sekarang. Terapis berfungsi sebagai guru dan model serta mengkonfrontasikan klien dengan cara-cara yang bisa membantu klien menghadapi kenyataan dan memenuhi kebutuhan - kebutuhan dasar tanpa merugikan dirinya sendiri ataupun orang lain.

Temuan ini sesuai dengan apa diungkapkan oleh Glasser (dalam Corey, 2015) yang mengatakan bahwa konseling realita mambantu para konseli dalam memenuhi kebutuhan-kebutuhan dasar psikologisnya yang mencakup kebutuhan untuk mencintai dan dicintai serta kebutuhan untuk merasakan bahwa kita berguna baik bagi diri kita sendiri maupun bagi orang lain. Hal senada (Gunarsa, 2005, p. 212). Mengatakan bahwa tujuan konseling realita adalah untuk memberikan kemungkinan dan kesempatan kepada klien, agar ia dapat mengembangkan kekuatan-kekuatan psikis yang dimilikinya untuk menilai prilaku sekarang dan apabila prilakunya tidak dapat memenuhi kebutuhankebutuhannya, maka memperoleh prilaku baru yang lebih efektif.

\section{SIMPULAN}

Kecemasan mengemukakan pendapat siswa kelas VIII SMP sebelum pemberian konseling realita termasuk dalam kategori sedang, meskipun masih ada yang memiliki kecemasan mengemukakan pendapat dalam kategori tinggi. Kecemasan mengemukakan pendapat yang tinggi pada siswa kelas VIII SMP sesudah pemberian konseling realita, berubah menjadi kategori sedang. Pengujian hipotesis membuktikan bahwa pelaksanaan konseling realita efektif dalam mengatasi tingkat kecemasan mengemukakan pendapat siswa kelas VIII SMP.

\section{REFERENSI}

Corey, G. (2015). Theory and practice of counseling and psychotherapy. Nelson Education.

Habsy, B. A. (2017). Model konseling kelompok cognitive behavior untuk meningkatkan self esteem siswa SMK. Perspektif Ilmu Pendidikan, 31(1), 21-35. doi: 10.21009/PIP.311.4 
Habsy, B. A. (2017). Filosofi ilmu bimbingan dan konseling Indonesia. Jurnal Pendidikan (Teori dan Praktik), 2(1), 1-11. doi: 10.26740/jp.v2n1.p1-11

Habsy, B. A. (2017). Seni memahami penelitian kualitatif dalam bimbingan dan konseling: Studi literatur. Jurnal Konseling Andi Matappa, 1(2), 90-100. doi: 10.31100/jurkam.v1i2.56

Habsy, B. A. (2018). Konseling rasional emotif perilaku: Sebuah tinjauan filosofis. Indonesian Journal of Educational Counseling, 2(1), 13-30. doi: 10.30653/001.201821.25

Habsy, B. A. (2018b). Model bimbingan kelompok PPPM untuk mengembangkan pikiran rasional korban bullying siswa SMK etnis Jawa. Jurnal Pendidikan (Teori dan Praktik), 2(2), 91-99. doi: 10.26740/jp.v2n2.p91-99

Hurlock, E. B. (2009). Psikologi perkembangan anak (Jilid 1). Jakarta: Erlangga.

Ghozali, I. (2012). Aplikasi analisis multivariate. Semarang: Badan Penerbit Universitas Diponegoro.

Gunarsa, S. D. (1991). Psikologi praktis: anak, remaja dan keluarga. BPK Gunung Mulia.

Hidayat, A., \& Sahrudin, A. (2016). Locus of control in late adolescence: Characteristics and ability of new students to overcome depression. GUIDENA: Jurnal Ilmu Pendidikan, Psikologi, Bimbingan dan Konseling, 6(2), 172-179. doi: 10.24127/gdn.v6i2.520

Kartono, (2013). Bimbingan dan konseling di sekolah dan madrasah (Berbasis integrasi), cetakan kelima. Jakarta: Raja Grafindo Persada.

Morgan. (2004). Komunikasi antar pribadi. Jakarta: Universitas Terbuka.

Prasetyono. (2009). Psikologi belajar. Cetak ke tiga. Jakarta: Rajawali Press.

Suryabrata, S. (2007). Psikologi pendidikan (suatu penyajian secara operasional). Yogyakarta: Rake Press.

Wahyuni, E. (2015). Hubungan self-effecacy dan keterampilan komunikasi dengan kecemasan berbicara di depan umum. Jurnal Komunikasi Islam, 5(1), 51-82. 